\title{
ANALISIS MOTIVASI BELAJAR INTRINSIK PADA PEMBELAJARAN MATEMATIKA KELAS XI SMA NEGERI 1 KEDUNGREJA
}

\author{
Alviansyah Putra Indrayadi ${ }^{*}$, Dwi Rachmanto², Nandita Ratih Dewi Lukito ${ }^{3}$, \\ Zulfa Nur Rokhisa ${ }^{4}$, Sumbaji Putranto ${ }^{5}$ \\ 1,2,3,4,5Prodi Pendidikan Matematika Fakultas Ilmu Tarbiyah dan Keguruan, UIN Sunan Kalijaga \\ Jalan Marsda Adisucipto, Yogyakarta, Indonesia \\ e-mail: ${ }^{1}$ alviansyahptrind@gmail.com; \\ Submitted: September 24,2021 \\ Revised: November 9, 2021 \\ Accepted: December 11, 2021 \\ corresponding author*
}

\begin{abstract}
Abstrak
Penelitian ini bertujuan untuk menganalis motivasi belajar intrinsik pada pembelajaran matematika siswa SMA Negeri 1 Kedungreja. Subjek pada penelitian ini adalah seorang guru matematika dan 20 siswa kelas XI-MIPA 4 SMA Negeri 1 Kedungreja. Deskriptif kualitatif adalah metode yang digunakan pada penelitian ini. Pengumpulan data dilakukan dengan kuesioner dan wawancara. Hasil penelitian menunjukkan bahwa terdapat 15 orang siswa dengan kategori motivasi belajar intrinsik tinggi dan 5 orang siswa berkategori sedang. Analisis rata-rata skor per indikator untuk kedua kategori motivasi belajar intrinsik menunjukkan bahwa semua indikator berada pada kategori tinggi baik motivasi tinggi maupun sedang. Namun selisih rata-rata skor yang paling tinggi di antara ketiga indikator lain adalah pada indikator kebiasaan baik dengan nilai selisih 0.81. Penghitungan tersebut juga terkonfirmasi melalui wawancara bahwa siswa bermotivasi belajar intrinsik tinggi akan mempelajari materi sebelumnya jika besok adalah jadwal pelajaran matematika, sedangkan siswa dengan kategori motivasi belajar intrinsik sedang menyatakan bahwa jika besok adalah jadwal pelajaran matematika mereka hanya melihat materi sebelumnya.
\end{abstract}

Kata Kunci: analisis, motivasi belajar intrinsik, pembelajaran matematika

\section{ANALYSIS OF INTRINSIC LEARNING MOTIVATION IN MATHEMATICS LEARNING CLASS XI SMA NEGERI 1 KEDUNGREJA}

\begin{abstract}
This study aims to analyze the intrinsic learning motivation in mathematics learning in SMA Negeri 1 Kedungreja students. The subjects in this study were a mathematics teacher and 20 students of class XIMIPA 4 SMA Negeri 1 Kedungreja. Qualitative descriptive is the method used in this study. Data collection was carried out by means of questionnaires and interviews. The results showed that there were 15 students with high intrinsic motivation category and 5 students with medium category. Analysis of the average score per indicator for the two categories of intrinsic learning motivation shows that all indicators are in the high category, both high and moderate motivation. However, the highest difference in average scores among the other three indicators is the good habits indicator with a difference of 0.81 . This calculation is also confirmed through interviews that students with high intrinsic motivation to learn will study the previous material if tomorrow is the mathematics lesson schedule while students with the intrinsic learning motivation category are stating that if tomorrow is the mathematics lesson schedule they will only look at the previous material.
\end{abstract}

Keywords: analysis, intrinsic learning motivation, mathematics learning

\section{Pendahuluan}

Sumbangsih ilmu matematika bagi kemajuan berbagai bidang kehidupan tak mungkin dipungkiri. Banyak konsep dalam matematika yang menginspirasi para saintis untuk menciptakan penemuan-penemuan baru. Tak heran matematika dijuluki sebagai ratu sekaligus pelayan untuk ilmu yang lain (Kamarullah, 2017). Hal tersebut menunjukkan pentingnya matematika dalam menunjang setiap bidang keilmuan tak terkecuali pendidikan. Bahkan menurut (Hazarida dkk., 2015) matematika memiliki peran dalam meningkatkan kualitas pendidikan. Sebagaimana telah diketahui bahwa pendidikan merupakan proses yang dijalani oleh setiap individu. 
Immanuel dalam teori pendidikannya menyimpulkan bahwa hanya melalui pendidikan lah seseorang akan menjadi manusia yang seutuhnya (Akbar, 2015). Mengingat pentingnya matematika dalam perkembangan ilmu pengetahuan, maka kaitannya dengan pendidikan, pembelajaran matematika di sekolah juga menjadi penting untuk diperhatikan. Inisiatif untuk memberi perhatian pada pembelajaran matematika sekolah tentu beralasan. Beberapa siswa masih menjadikan matematika sebagai pelajaran yang tidak disukai (Chandra, 2019). Mereka menganggap matematika sebagai pelajaran yang sulit (Senjaya dkk., 2017).

Motivasi belajar merupakan aspek penting dalam pembelajaran matematika. Motivasi belajar menurut Hamalik, turut berperan sebagai penggerak yang menjadi penentu kecepatan siswa dalam merespon kegiatan belajar mereka (Sugiyo \& Abadi, 2019). Selain itu motivasi belajar menjadi faktor utama yang menggerakkan siswa untuk aktif dalam aktivitas belajar (Wahyuni dkk., 2017). Pernyataan tersebut memberikan konsekuensi bagi guru, sebagai fasilitator siswa dalam belajar, untuk mengetahui motivasi belajar siswa. Bagi guru mengenali motivasi belajar akan berguna dalam upaya meningkatkan semangat belajar siswa sedangkan bagi siswa mengenali motivasi diri dalam belajar penting dalam menumbuhkan semangat belajar (Arianti, 2018). Menurut (Emda, 2017) motivasi belajar adalah dorongan dalam diri seseorang guna mencapai suatu tujuan. Siswa yang memiliki motivasi belajar tinggi akan cenderung memiliki peluang lebih besar mencapai keberhasilan dalam belajar matematika dibandingkan dengan siswa bermotivasi rendah. Hal tersebut sejalan dengan studi yang dilakukan (Winata \& Friantini, 2019) dan (Sandy dkk., 2016) yang menyatakan bahwa terdapat pengaruh motivasi belajar terhadap prestasi belajar matematika siswa. Muhibbin membagi motivasi belajar secara garis besar menjadi dua yaitu intrinsik dan ekstrinsik (Azis, 2017). Motivasi yang berasal dari dalam diri individu disebut dengan motivasi intrinsik (Asmar dkk., 2019). Sedangkan motivasi ekstrinsik adalah dorongan untuk melakukan belajar yang berasal dari luar individu (Ledford dkk., 2013).

Sayangnya terdapat beberapa problematika yang muncul hubungannya dengan motivasi belajar. Menurut (Rohman \& Karimah, 2018; Sabrina dkk., 2017) motivasi belajar siswa dalam pembelajaran matematika masih tergolong rendah. Fakta demikian diperparah dengan sebagian orang tua dan guru yang terkesan tak mau tahu akan hal tersebut (Lestari, 2012).
Dalam pembelajaran matematika dorongan berupa motivasi yang berasal dari dalam (intrinsik) akan menjadi penggerak utama siswa untuk melakukan kegiatan belajar matematika. Bukan tanpa alasan, menurut (Fuqoha dkk., 2018) motivasi intrinsik juga turut menentukan hasil belajar matematika. Lebih lanjut motivasi intrinsik timbul murni atas kesadaran diri siswa (Azis, 2017), sehingga siswa akan dengan senang hati melakukan berbagai aktivitas belajar matematika dan pembelajaran pun akan menjadi bermakna. Selain itu motivasi intrinsik pada pembelajaran matematika lebih bermanfaat daripada motivasi ekstrinsik dalam proses dan hasil aktivitas matematika (Mueller dkk., 2011). Seorang siswa yang memiliki motivasi intrinsik dalam dirinya, maka ia akan melakukan kegiatannya tanpa perlu lagi motivasi dari luar (Sari, 2018).

Studi tentang motivasi belajar intrinsik pada pembelajran matematika sudah banyak dilakukan. Penelitian tersebut sudah dilakukan pada jenjang SD dan SMP (V. Dewi dkk., 2019; Rosnawati dkk., 2013). Bahkan penelitian pada jenjang SMA juga sudah dilakukan oleh (Jumarniati, 2016) dengan subjek siswa kelas X. Salah satu hasil riset (Jumarniati, 2016) tersebut menyatakan bahwa terdapat pengaruh yang signifikan motivasi belajar matematika intrinsik bagi hasil belajar matematika. Dari beberapa penelitian tersebut juga sepanjang pengetahuan peneliti, penelitian tentang motivasi belajar intrinsik pada pembelajaran matematika dengan subjek siswa kelas XI SMA belum pernah dilakukan. Oleh karena itulah penelitian ini hendak meneliti motivasi belajar intrinsik pada pembelajaran matematika dengan subjek siswa kelas XI SMA.

Berdasarkan uraian permasalahan tersebut, penelitian ini bermaksud untuk menganalisis motivasi belajar intrinsik pada pembelajaran matematika dengan rumusan masalah, "Bagaimanakah motivasi belajar intrinsik pada pembelajaran matematika?". Urgensi penelitian ini didasarkan pada fakta bahwa dorongan dalam diri siswa di pembelajaran matematika menduduki posisi yang penting. Adapun pemilihan subjek penelitian yakni siswa kelas XI-MIPA 4 SMA Negeri 1 Kedungreja dikarenakan menurut hasil wawancara dengan guru, siswa di kelas tersebut tergolong aktif dan responsif sehingga akan memudahkan peneliti dalam proses pengumpulan data.

\section{Metode Penelitian}

Metode yang digunakan pada penelitian ini adalah deskriptif kualitatif dengan alur penelitian 
pada Gambar 1. Pengumpulan data dilakukan melalui kuesioner dengan instrumen yang diadopasi dari penelitian Danar (2012) dan juga melalui wawancara. Kuesioner tersebut terdiri dari 26 butir pernytaan dan setiap pernyataan diberikan 4 alternatif jawaban yakni sangat setuju (SS), setuju (S), tidak setuju (TS), dan sangat tidak setuju (STS).

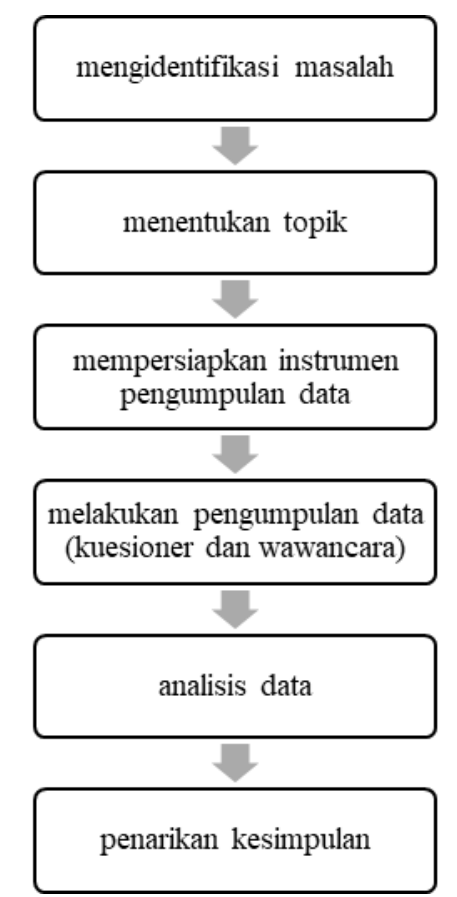

Gambar 1. Diagram alur penelitian

Pedoman untuk wawancara pada penelitian ini terdiri dari dua yaitu untuk subjek guru dan siswa. Pertanyaan yang termuat di dalamnya mewakili setiap indikator penelitian ini. Adapun indikator yang hendak diukur pada penelitian ini sebagaimana pada penelitian Danar (2012) tertera pada Tabel 1.

Tabel 1. Indikator yang hendak diukur

\begin{tabular}{lc}
\hline No. & Indikator yang diukur \\
\hline 1 & Keinginan diri \\
2 & Kepuasan \\
3 & Kebiasan baik \\
4 & Kesadaran \\
\hline
\end{tabular}

Subjek penelitian ini yaitu seorang guru matematika dan 20 siswa kelas XI-MIPA 4, SMA Negeri 1 Kedungreja. Penentuan subjek penelitian menggunaan teknik purposive sampling dengan menetapkan kriteria tertentu (Sugiyono, 2016). Kriteria tertentu tersebut adalah subjek yang aktif serta responsif sehingga memudahkan peneliti dalam proses pengumpulan data. Setelah instrumen berupa kuesioner dan pedoman wawancara telah disusun dan sampel telah dipilih, maka pengambilan data melalui kuesioner dilakukan. Kuesioner disediakan dalam Google Form. Setelah data kuesioner terkumpul dan dianalisis, pengambilan data melalui wawancara dilakukan. Analisis berupa penghitungan skor hingga pengkategorian setiap subjek menggunakan Microsoft Excel. Pengkategorian tersebut berdasarkan total skor angket setiap subjek sebagaimana tertera pada Tabel 2. Subjek dalam wawancara (untuk siswa) dipilih secara purposive dengan mempertimbangkan hasil analisis kuesioner yaitu interpretasi jumlah skor angket untuk setiap responden pada penelitian Danar (2012). Setiap kategori tersebut dipilih satu orang responden untuk diwawancara guna mendapat informasi terkait gambaran motivasi intrinsik mereka dalam pembelajaran matematika.

Tabel 2. Interpretasi jumlah skor angket setiap responden

\begin{tabular}{cc}
\hline Rentang jumlah skor & Kategori \\
\hline$\geq 78$ & Tinggi \\
$52<$ Jumlah Skor $<78$ & Sedang \\
$\leq 52$ & Rendah \\
\hline
\end{tabular}

Setelah semua data terkumpul, selanjutnya data secara keseluruhan dianalisis. Analisis juga mempertimbangkan interpretasi rata-rata skor setiap indikator untuk setiap kategori. Interpretasi terhadap rata-rata tersebut berpedoman pada Tabel 3 (Danar, 2012).

Tabel 3. Interpretasi rata-rata setiap indikator

\begin{tabular}{cc}
\hline Rentang rata-rata & Kateogi \\
\hline $3.6-4.0$ & Sangat Tinggi \\
$2.6-3.5$ & Tinggi \\
$1.6-2.5$ & Sedang \\
$0.0-1.5$ & Rendah \\
\hline
\end{tabular}

Untuk memastikan keabsahan data yang diperoleh, digunakan triangulasi. Triangulasi pada penelitian ini adalah triangulasi metode. Triangulasi metode merupakan pengumpulan data yang sama menggunakan metode atau teknik yang berbeda (Bachri, 2010). Pada penelitian ini triangulasi metode berupa angket dan wawancara.

\section{Hasil dan Pembahasan}

\subsection{Hasil}

Data kuesioner yang telah terkumpul, selanjutnya dilakukan penghitungan skor motivasi intrinsik untuk setiap subjek. Dari 20 siswa yang menjadi subjek penelitian, mayoritas siswa berada pada kategori tinggi motivasi belajar intrinsiknya dengan rincian 15 (75\%) siswa berada pada kategori motivasi intrinsik tinggi, $5(25 \%)$ siswa berada pada kategori sedang, dan $0(0 \%)$ siswa yang masuk kategori rendah. Hasil penghitungan tersebut tertera pada Tabel 4 . 
Tabel 4. Hasil kuesioner

\begin{tabular}{ccc}
\hline Kode Siswa & $\begin{array}{c}\text { Jumlah Skor } \\
\text { Kuesioner }\end{array}$ & Kategori \\
\hline 21401 & 96 & Tinggi \\
21402 & 76 & Sedang \\
21403 & 70 & Tinggi \\
21404 & 102 & Tinggi \\
21405 & 84 & Tinggi \\
21406 & 80 & Tinggi \\
21407 & 70 & Sedang \\
21408 & 98 & Tinggi \\
21409 & 97 & Tinggi \\
21410 & 85 & Tinggi \\
21411 & 98 & Tinggi \\
21412 & 89 & Tinggi \\
21413 & 83 & \\
\hline
\end{tabular}

\begin{tabular}{ccc}
\hline 21414 & 93 & Tinggi \\
21415 & 77 & Tinggi \\
21416 & 82 & Sedang \\
21417 & 72 & Tinggi \\
21418 & 71 & Sedang \\
21419 & 95 & Sedang \\
21420 & 103 & Tinggi \\
& & Tinggi \\
\hline
\end{tabular}

Hasil angket juga dianalisis untuk setiap kategori dan indikator. Skor yang diperoleh setiap subjek dikelompokkan berdasarkan kategori. Kemudian dicari rata-rata skor per indikator. Hasil analisis menunjukkan bahwa rata-rata skor setiap indikator untuk setiap kategori motivasi berada pada kategori tinggi. Analisis tersebut terdapat pada Tabel 5 dan Tabel 6.

Tabel 5. Analisis rata-rata skor setiap indikator untuk setiap kategori motivasi

\begin{tabular}{ccccc}
\hline Indikator & $\mathbf{1}$ & $\mathbf{2}$ & $\mathbf{3}$ & $\mathbf{4}$ \\
\hline Rata-rata Skor Motivasi Tinggi & 3.56 & 3.43 & 3.47 & 3.47 \\
Kategori & Tinggi & Tinggi & Tinggi & Tinggi \\
Rata-rata Skor Motivasi Sedang & 2.96 & 2.70 & 2.66 & 2.84 \\
Kategori & Tinggi & Tinggi & Tinggi & Tinggi \\
\hline
\end{tabular}

Tabel 6. Hasil kuesioner

\begin{tabular}{ccc}
\hline Indikator & $\begin{array}{c}\text { Rata- } \\
\text { rata }\end{array}$ & Kategori \\
\hline Keinginan Diri & 3.41 & Tinggi \\
Kepuasan & 3.25 & Tinggi \\
Kebiasaa Baik & 3.26 & TInggi \\
Kesadaran & 3.31 & Tinggi \\
\hline
\end{tabular}

Setelah data hasil kuesioner selesai dihitung, langkah selanjutnya adalah wawancara. Pemilihan subjek dilakukan dengan melihat skor tertinggi (atau skor di bawahnya jika tidak memungkinkan) pada masing-masing kategori. Berdasarkan hasil Tabel 4 pula, wawancara kepada subjek siswa hanya dilakukan kepada seorang siswa berkategori tinggi dan seorang siswa yang lain dengan kategori sedang. Dengan demikian, diharapkan data yang diberikan dapat menggambarkan secara representatif motivasi belajar intrinsik pada pembelajaran matematika untuk setiap kategori.

Hasil wawancara dengan siswa berkategori tinggi, sedang, serta seorang guru matematika akan disampaikan berikut.

\section{Indikator 1: Keinginan Diri}

Pada indikator keinginan diri, siswa dengan motivasi intrinsik tinggi akan mengerjakan dengan sungguh-sungguh tugas yang diberikan guru. Ketika menemui soal matematika yang sukar mereka akan bertanya kepada teman atau mencari dari referensi lain. Adapun siswa dengan kategori motivasi intrinsik sedang akan mengerjakan tugas yang diberikan guru dengan melihat referensi lainnya serta bertanya kepada teman atau mencari referensi lain jika mengalami kesulitan dalam mengerjakan soal matematika. Sedangkan menurut guru, pada indikator keinginan diri terdapat tiga karakateristik siswa. Ketika mendapat soal yang sulit, siswa yang pandai dan rajin akan lebih termotivasi untuk segera menyelesaikannya sedangkan siswa yang biasa-biasa saja akan nampak kebingungan dan siswa yang malas hanya menunggu jawaban dari temannya. Berikut adalah kutipan transkrip hasil wawancara dengan guru.

$\begin{array}{lll}\text { Peneliti : } & \text { "Bagaimana pengamatan Guru ketika } \\ & \text { siswa mendapat soal yang sukar?" } \\ \text { Guru } & \text { : } & \text { "Untuk pertanyaan tersebut ada tiga } \\ & \text { jawabannya. Siswa yang pandai dan } \\ & \text { rajin akan segera menyelesaikannya. } \\ & \text { Namun siswa dengan kategori sedang } \\ & \text { akan mengalami kebingungan dan } \\ & \text { siswa yang malas cenderung hanya } \\ & \text { menunggu jawaban dari teman." }\end{array}$

\section{Indikator 2: Kepuasaan}

Untuk indikator kepuasan siswa dengan kategori tinggi pada motivasi belajas intrinsiknya merasa bersyukur jika mendapat nilai matematika memuaskan dan berusaha untuk meningkatkannya. Sedangkan untuk siswa kategori sedang akan merasa senang ketika mendapat nilai matematika yang memuaskan sehingga merasa semangat belajar. Dalam wawancara pada kategori ini guru 
menyatakan bahwa siswa akan merasa senang ketika mendapat nilai matematika yang memuaskan. Berikut disajikan kutipan wawancara guru dengan peneliti.

$$
\begin{aligned}
\text { Peneliti : } & \text { "Bagaimana pengamatan Guru ketika } \\
& \text { siswa mendapat nilai matematika } \\
& \text { yang memuaskan?" } \\
\text { Guru : } & \text { "Ya tentunya siswa akan merasa } \\
& \text { senang kalau mendapat nilai } \\
& \text { matematika yang demikian." }
\end{aligned}
$$

\section{Indikator 3: Kebiasaan Baik}

Siswa dengan kategori tinggi pada indikator kebiasaan baik akan mempelajari materi sebelumnya dan materi yang akan diberikan jika besok adalah jadwal pelajaran matematika. Ketika guru menjelaskan mereka mendengarkan memperhatikan dan menyimak. Berikut adalah kutipan wawancara peneliti dengan siswa kategori tinggi.

$\begin{array}{ll}\text { Peneliti : } & \text { "Apa yang akan Anda lakukan jika } \\ & \text { mengetahui bahwa besok adalah } \\ & \text { jadwalnya matematika?" } \\ \text { Siswa : } & \text { "Saya akan mempelajari materi } \\ & \text { sebelumnya dan materi yang akan } \\ & \text { diberikan." } \\ \text { Peneliti : } & \text { "Baik. Kemudian apa yang Anda } \\ & \begin{array}{l}\text { lakukan ketika guru matematika } \\ \text { sedang memberikan materi?" }\end{array} \\ \text { Siswa } & \text { "Saya mendengarkan, } \\ & \text { memperhatikan, dan menyimak." }\end{array}$

Sedangkan siswa dengan kategori motivasi intrinsik sedang akan melihat materi sebelumnya jika besok adalah jadwal pelajaran matematika. Saat guru menjelaskan mereka memperhatikan kemudian mencatat. Kutipan wawancara peneliti dengan siswa kategori sedang disampaikan berikut.

$\begin{aligned} & \text { Peneliti : } \begin{array}{l}\text { "Apa yang akan Anda lakukan jika } \\ \text { mengetahui bahwa besok adalah } \\ \text { jadwalnya matematika?" }\end{array} \\ & \text { Siswa : } \begin{array}{l}\text { "Saya melihat-lihat materi yang } \\ \text { sebelumnya agar tidak lupa." }\end{array} \\ & \text { Peneliti : } \text { "Baik. Kemudian apa yang Anda } \\ & \begin{array}{l}\text { lakukan ketika guru matematika } \\ \text { sedang memberikan materi?" }\end{array} \\ & \text { Siswa }: \begin{array}{l}\text { "Memperhatikan guru, jika sudah } \\ \text { selesai kemudian baru mencatat } \\ \text { materinya." }\end{array}\end{aligned}$

Dalam wawancara terkait dengan indikator kebiasaan baik guru menyampaikan bahwa hanya sebagian siswa yang memperhatikan dengan sungguh-sungguh. Sebagian siswa yang lain memperhatikan namun dengan tatapan kosong. Berikut kutipan wawancara peneliti dengan guru.

$\begin{aligned} \text { Peneliti : } & \text { "Kemudian menurut pengamatan, } \\ & \text { bagaimanakah siswa ketika Guru } \\ & \text { sedang memberikan materi?" } \\ \text { Guru : } & \text { "Ketika saya memberikan materi } \\ & \text { sebagian siswa memperhatikan } \\ & \text { dengan sungguh-sungguh. Namun } \\ & \text { beberapa siswa yang lain } \\ & \text { memperhatikan dengan tatapan yang } \\ & \text { kosong." }\end{aligned}$

\section{Indikator 4: Kesadaran}

Untuk indikator terakhir yaitu kesadaran. Berdasarkan wawancara diketahui bahwa siswa dengan motivasi intrinsik tinggi akan menyelesaikan tugas dengan kesadaran sendiri. Siswa dengan motivasi intrinsik sedang juga melakukan hal yang sama yakni menyelesaikan tugas dengan kesadaran sendiri. Sedangkan menurut guru, ketika diberikan tugas banyak siswa yang nampak sedih dengan hal tersebut.

\subsection{Pembahasan}

\section{Indikator 1: Keinginan Diri}

Dalam proses pembelajaran indikator motivasi berupa keinginan diri adalah bagian penting. Keinginan diri merupakan kehendak yang timbul dari diri sendiri (Badan Pengembangan dan Pembinaan Bahasa, Kementerian Pendidikan dan Kebudayaan Republik Indonesia, 2016). Tak heran ia menjadi bagian dari motivasi belajar intrinsik.

Data pada penelitian ini menunjukkan bahwa siswa dengan kategori motivasi tinggi maupun sedang mendapatkan predikat tinggi untuk indikator keinginan diri sebagaimana disampaikan pada Tabel 5. Hal tersebut didasarkan juga pada skor rata-rata indikator tersebut yang diperoleh berada pada rentang 2.6 - 3.5 yaitu 3.41 sebagaimana tertera pada Tabel 6. Hasil wawancara juga menunjukkan bahwa keinginan diri siswa termasuk tinggi adalah ketika mereka menemui soal yang sulit maka siswa akan bertanya kepada temannya yang dirasa bisa atau mencari referensi lain. Pernyataan tersebut senada dengan pendapat Cahyaningsih (2012) bahwa salah satu ciri siswa dengan motivasi tinggi adalah ulet saat menjumpai kesulitan dalam belajar. Siswa yang memiliki semangat dan keinginan tinggi akan berusaha menyelesaikan tugas yang diberikan guru (Zulfa, 2019). Dengan begitu, siswa mempunyai kemauan kuat untuk meraih prestasi belajar yang baik (Sarbani \& Subandoro, 2017).

\section{Indikator 2: Kepuasan}

Kepuasan adalah kesimpulan menurut hasil interaksi antara harapan dan pengalaman setelah mengalami perlakuan tertentu (Yasir dkk., 2017). Lebih khusus pada konteks belajar, menurut 
Sopiatin, kepuasan merupakan respon positif yang diberikan siswa terhadap proses pembelajaran karena adanya kesesuaian antara harapan dan kebutuhan dengan realita yang dirasakan (Nuramalina dkk., 2019). Kepuasan akan mencerminkan perasaan siswa terhadap matematika itu sendiri yang nampak dari perilaku siswa tersebut dalam belajar matematika (Saputriana, 2020).

Pada penelitian ini, rata-rata skor untuk indikator kepuasan baik motivasi tinggi maupun sedang berada pada kategori tinggi. Data tersebut sejalan dengan hasil wawancara. Siswa akan merasa bersyukur sebagai wujud rasa senang ketika mendapat nilai matematika yang memuaskan serta berusaha meningkatkannya. Hasil ini sejalan dengan teori yang dikemukakan oleh Goleman (2002) bahwa siswa yang memperoleh hasil belajar matematika memuaskan akan merasa bangga dan senang.

Menurut Chang dan Fisher, dalam pembelajaran, tingkat kepuasan siswa merupakan komponen yang sangat penting dalam rangka memperoleh pengetahuan maupun keterampilannya (Uka, 2014). Selain itu pentingnya kepuasan siswa dalam belajar disebabkan karena kepuasan akan memberikan gambaran keadaan emosional siswa terhadap sesuatu yang sedang dipelajari (Magi, 2019). Oleh karena itu dalam pembelajaran matematika tingginya tingkat kepuasan sangat penting agar hasil yang tinggi dapat dicapai (Nartani dkk., 2015).

\section{Indikator 3: Kebiasaan Baik}

Kebiasaan baik sangatlah penting bagi siswa. Kebiasaan belajar adalah bagian dari kebiasaan baik. Djaali mengartikan kebiasan belajar sebagai cara melakukan sesuatu yang melekat dalam diri siswa meliputi waktu siswa menerima pelajaran, membaca buku, dan mengerjakan tugas, serta manajemen waktu dalam menyelesaikannya (Nawawi, 2016). Kebiasaan belajar merupakan hal penting dalam menentukan keberhasilan belajar (Paramika, 2017).

Pada penelitian ini, sebagiamana pada Tabel 5, rata-rata skor indikator kebiasaan baik untuk kategori motivasi tinggi adalah 3.47 dan 2.66 untuk motivasi sedang. Rata-rata untuk motivasi tinggi lebih besar sebanyak 0.81 dibanding rata-rata motivasi sedang. Angka tersebut menjadi selisih tertinggi di antara ketiga indikator lain. Hal demikian terkonfirmasi juga melalui wawancara bahwa siswa bermotivasi tinggi akan mempelajari materi sebelumnya jika besok adalah jadwal pembelajaran matematika dan siswa yang bermotivasi sedang hanya sekadar melihat materi sebelumnya jika besok adalah jadwal pembelajaran matematika.

Berangkat dari hasil tersebut kebiasaan baik, termasuk di dalamnya adalah kebiasaan belajar, menjadi penting untuk diperhatikan. Untuk mengembangkan kemampuan siswa, kebiasaan belajar harus diperhatikan dengan serius (Siahi \& Maiyo, 2015). Penelitian yang dilakukan (Bassey \& Edoho, 2018) menunjukkan adanya korelasi antara kebiasaan belajar terhadap prestasi belajar matematika. Lebih lanjut Rahayu (R. Dewi dkk., 2020) dalam studinya yang menyimpulkan bahwa terdapat pengaruh kebiasaan belajar terhadap hasil belajar matematika.

\section{Indikator 4: Kesadaran}

Berdasarkan rata-rata hasil indikator kesadaran siswa bermotivasi instrinsik tinggi adalah 3.47 dan sedang sebesar 2.84. Indikator kesadaran dikategorikan tinggi. Hal ini didukung dengan hasil wawancara yakni siswa menyelesaikan tugas dengan kesadaran sendiri. Penelitian yang dilakukan oleh (Pradita, 2014) menunjukkan bahwa tingginya kesadaran siswa mengindikasikan siswa tersebut memahami tujuan yang hendak dicapainya. Mengerjakan tugas atas kesadaran sendiri merupakan upaya siswa untuk mencapai hasil yang maksimal sebagai tujuannya dalam belajar matematika.

Kesadaran merupakan hal yang penting untuk dikembangkan oleh siswa (Ahmad \& Nasution, 2019). Dalam belajar, kesadaran sangat dibutuhkan agar siswa belajar dengan kemauan sendiri dan rela belajar tanpa harus diperintah atau diawasi guru (Sukoyo, 2014). Hal ini didukung dengan hasil wawancara yaitu menyelesaikan tugas dengan kesadaran sendiri. Penelitian (Astuti dkk., 2019) menunjukkan bahwa semakin tinggi kesadaran diri maka semakin tinggi dorongan mengerjakan tugas akademik.

\section{Kesimpulan}

Kesimpulan penelitian ini adalah motivasi belajar intrinsik siswa pada pembelajaran matematika dengan subjek sebagaimana telah diuraikan menunjukkan bahwa sebagian besar berada di kategori tinggi. Lebih lanjutnya subjek siswa pada penelitian ini menurut hasil angket terbagi menjadi dua yakni siswa dengan motivasi intrinsik tinggi dan siswa dengan motivasi intrinsik sedang. Siswa dengan kategori tinggi tersebut akan mempelajari materi sebelumnya jika besok adalah jadwal pembelajaran matematika dan siswa yang bermotivasi sedang hanya sekadar melihat materi 
sebelumnya jika besok adalah jadwal pembelajaran matematika.

Penelitian selanjutnya sebagai bentuk tindak lanjut penelitian ini menarik untuk dilakukan. Salah satunya yakni penelitian yang hendak menganalisis faktor-faktor yang mempengaruhi motivasi belajar intrinsik pada pembelajaran matematika. Dengan demikian penelitian ini dapat dijadikan salah satu referensi.

\section{Daftar Pustaka}

Abha, M. (2013). Pendidikan Dalam Perspektif AlQur'an. Jurnal Al-Afkar, 2(2), 22-36.

Ahmad, M., \& Nasution, D. (2019). Pembinaan Kesadaran Belajar Matematika Melalui Pendekatan Historis Pada Siswa SMA Negeri 6 Padangsidimpuan. Martabe: Jurnal Pengabdian Masyarakat, 2(1), 45-54.

Akbar, T. S. (2015). Manusia dan Pendidikan Menurut Pemikiran Ibn Khaldun dan John Dewey. Jurnal Ilmiah Didaktika, 15(2), 222-243. https://doi.org/10.22373/jid.v15i2.582

Arianti, A. (2018). Peranan Guru dalam Meningkatkan Motivasi Belajar Siswa. Didaktika (Jurnal Pendidikan), 12(2), 117-134.

Asmar, R., Kurniaman, O., \& Hermita, N. (2019). Analisis Motivasi Intrinsik Belajar Siswa Kelas V Sekolah Dasar Se-Gugus 1 Kecamatan Payung Sekaki Kota Pekanbaru. Jurnal Pajar (Pendidikan dan Pengajaran), 3(1), 93-100.

Astuti, J., Mayangsari, M., \& Zwagery, R. (2019). Hubungan Kesadaran Diri Dengan Flow Akademik Pada Siswa di Daerah Lahan Gambut. Jurnal Kognisia, 2(2), 68-74.

Azis, A. (2017). Pengaruh Motivasi Intrinsik dan Motivasi Ekstrinsik Terhadap Prestasi Belajar Ekonomi Kelas X Peserta Didik Kelas X di SMKN 4 Makassar [Tesis]. Universitas Negeri Makassar.

Bachri, B. (2010). Meyakinkan Validitas Data Melalui Triangulasi Pada Penelitian Kualitatif. Jurnal Teknologi Pendidikan, 10(1), 46-62.

Badan Pengembangan dan Pembinaan Bahasa, Kementerian Pendidikan dan Kebudayaan Republik Indonesia. (2016). KBBI Daring. Dalam KBBI Daring. Badan Pengembangan dan Pembinaan Bahasa, Kementerian Pendidikan dan Kebudayaan Republik Indonesia. https://kbbi.kemdikbud.go.id/entri/keinginan

Bassey, U., \& Edoho, E. (2018). Sudy Habits and Students' Achievement in Mathematics in Ikono Local Government Area, Akwa Ibom State. British Journal of Education, 7(1), 20-26.

Cahyaningsih, D. (2012). Upaya Peningkatan Motivasi Belajar Siswa Kelas VIII B Melalui Penerapan Metode Kooperatif Tipe Team Assisted Individualization (TAI) dalam Pembelajaran IPS di SMP N 2 Mrebet Prurbalingga [Skripsi]. Universitas Negeri Yogyakarta.

Chandra, F. (2019). Penerapan Sistem Pendidikan Pramuka Dalam Pembelajaran Matematika Guna Meningkatkan Disposisi Matematis Siswa. AXIOMA Jurnal Program Studi Pendidikan Matematika Universitas Islam Jember, 4(1), 16 26.

Danar, V. (2012). Hubungan Motivasi Belajar Intrinsik dan Ekstrinsik Siswa Dengan Prestasi Belajar Siswa Kelas X Kompetensi Keahlian Teknik Audio Video SMK Ma'arif 1 Wates [Skripsi]. Universitas Negeri Yogyakarta.

Dewi, R., Artayasa, I., \& Yamin, M. (2020). Kotribusi Kebiasaan Belajar Terhadap Prestasi IPA Siswa SMP. Jurnal Pijar MIPA, 15(3), 288-292.

Dewi, V., Syamsuri, S., \& Khaerunnisa, E. (2019). Karakteristik Motivasi Ekstrinsik dan Intrinsik Siswa SMP dalam Belajar Matematika. Jurnal Penelitian Pengajaran Matematika, 1(2), 116128.

Emda, A. (2017). Kedudukan Motivasi Belajar Siswa Dalam Pembelajaran. Lantanida Journal, 5(2), 93-196.

Fuqoha, A. A. N., Budiyono, B., \& Indriati, D. (2018). Motivation in Mathematics Learning. Pancaran Pendidikan, $\quad 7(1), \quad$ 202-209. https://doi.org/10.25037/pancaran.v7i1.151

Goleman, D. (2002). Working with Emotional Intelligence. Jakarta: PT Gramedia Pustaka Utama.

Hazarida, R., Deswita, H., \& Rino, R. (2015). Analisis Motivasi Belajar Matematika Siswa Kelas VIII SMP Negeri 1 Rambah Hilir. Jurnal Mahasiswa Prodi Matematika UPP.

Jumarniati, J. (2016). Pengaruh Motivasi terhadap Hasil Belajar Matematika Siswa Kelas X SMAN di Kecamatan Biringkanaya. Prosiding Seminar Nasional, 2(1), 328-336.

Kamarullah. (2017). Pendidikan Matematika di Sekolah Kita. Al Khawarizmi: Jurnal Pendidikan dan Pembelajaran Matematika, 1(1), 21-32.

Ledford, G., Gerhart, B., \& Fang, M. (2013). Negative Effects of Extrinsic Rewards on Intrinsic Motivation: More Smoke Than Fire. World at Work Journal.

Lestari, T. (2012). Kontribusi Taktik Mengajar, Penampilan Guru, dan Disiplin Guru dalam Kelas terhadap Motivasi Belajar Siswa SMP Negeri Gondangrejo Kabupaten Karanganyar [Tesis]. Universitas Muhammadiyah Surakarta.

Magi, M. (2019). Survei Kepuasan Siswa terhadap Guru Mata Pelajaran Matematika Ditinjau dari Kemampuan Kreativitas dan Penguasaan Materi SPLDV SMP Negeri 2 Nanggulan [Skripsi]. Universitas Mercu Buana Yogyakarta.

Mueller, M., Yankelewitz, D., \& Maher, C. (2011). Sense Making as Motivation in Doing Mathematics: Results from Two Studies. The Mathematics Educator, 20(2), 33-43.

Nartani, C., Hidayat, R., \& Sumiyati, Y. (2015). Kepuasan Siswa Dalam Pembelajaran Matematika Kontekstual di SD Taman Muda 
Kota Yogyakarta. Jurnal Varidika, 27(2), 138143.

Nawawi, K. (2016). Pengaruh Kebiasaan Belajar dan Motivasi Belajar Terhadap Hasil Belajar Siswa Kelas V SD Gugus Dewi Sartika dan Gugus Hasanudin Kota Tegal [Skripsi]. Universitas Negeri Semarang.

Nuramalina, N., Basuki, I., \& Suyono. (2019). Pengaruh Model Kolaboratif Berbasis Masalah Terhadap Kepuasan Belajar Siswa Sekolah Dasar. Jurnal Pendidikan: Teori, Penelitian, dan Pengembangan, 4(1), 29-35.

Paramika, F. (2017). The Correlation Between Study Habits and Academic Achievement of Undergraduate EFL Students of English Education Study Program of UIN Raden Fatah Palembang [Skripsi]. UIN Raden Fatah.

Pradita, I. (2018). Kesadaran Siswa dalam Mengikuti Proses Pembelajaran (Studi Deskriptif pada Siswa Kelas VIII SMP Negeri 1 Ceper) [Skripsi]. Universitas Sanata Dharma.

Rohman, A., \& Karimah, S. (2018). Faktor-faktor yang Mempengaruhi Rendahnya Motivasi Belajar Siswa Kelas XI. Jurnal At-Taqaddum, 10(1), 95108.

Rosnawati, R., Hasjmy, M., \& Salimi, A. (2013). Peningkatan Motivasi Peserta Didik dalam Pembelajaran Matematika Menggunakan Metode Permainan Kelas II SDN 01 Sintang. Jurnal Pendidikan dan Pembelajaran Khatulistiwa, 3(2).

Sabrina, R., Fauzi, F., \& Yamin, M. (2017). Faktorfaktor Penyebab Rendahnya Motivasi Belajar Siswa dalam Proses Pembelajaran Matematika di Kelas V SD Negeri Garot Geuceu Aceh Besar. Jurnal Ilmiah Pendidikan Guru Sekolah Dasar FKIP Unsyiah, 2(4), 108-118.

Sahrudin, A. (2014). Implementasi Strategi Pembelajaran Discovery Untuk Meningkatkan Kemampuan Pemecahan Masalah Matematis dan Motivasi Belajar Siswa SMA. Jurnal Pendidikan Unsika, 2(1), 1-12.

Sandy, K., Hadiyanti, Y., \& Tandililing, P. (2016). Pengaruh Motivasi Belajar Terhadap Prestasi Belajar Matematika Pada Siswa Kelas VIII SMP Negeri 2 Jayapura. Jurnal Ilmiah Matematika dan Pembelajarannya, 3(1), 17-22.

Saputriana, R. (2020). Pengaruh Spiritualitas di Tempat Kerja dan Stres Kerja terhadap Perilaku Menyimpang di Kalangan Guru SMA Muhammadiyah Yogyakarta Melalui Kepuasan Kerja Sebagai Variabel Mediasi (Studi pada SMA Muhammadiyah 3 \& 7 Yogyakarta [Skripsi]. Universitas Muhammadiyah Yogyakarta.
Sarbani, Y., \& Subandoro, P. (2017). Memahami Motivasi Berprestasi dan Manfaat Penggunaan Gawai bagi Generasi Digital Native. Vocatio Jurnal Ilmiah Ilmu Adiminstrasi dan Sekretari, $1(2), 1-11$.

Sari, I. (2018). Motivasi Belajar Mahasiswa Program Studi Manajemen Dalam Penguasaan Keterampilan Berbicara (Speaking) Bahasa Inggris. Jurnal Manajemen Tools, 9(1), 41-52.

Senjaya, A., Sudirman, \& Supriyatno. (2017). Kesulitan-Kesulitan Siswa Dalam Mempelajari Matematika Pada Materi Garis dan Sudut di SMP N 4 Sindang. M A T H L I N E: Jurnal Matematika dan Pendidikan Matematika, 2(1), 11-28. https://doi.org/10.31943/mathline.v2i1.32

Siahi, E., \& Maiyo, J. (2015). Study of The Relationship Between Study Habits and Academic Achievement of Students: A Case of Spicer Higher Secondary School, India. International Journal of Educational Administration and Policy Studies, 7(7), 134-141.

Sugiyo, Q., \& Abadi, A. (2019). Konsep dan Peran Motivasi Dalam Belajar Matematika. 957-961.

Sugiyono, S. (2016). Konsep dan Peran Motivasi Dalam Belajar Matematika. Bandung: CV Alfabeta.

Sukoyo, M. (2014). Pengaruh Kesadaran Belajar, Kemandirian Belajar, dan Fasilitas Bengkel Terhadap Kompetensi Siswa Pada Mata Diklat Dasar Instalasi Listrik di SMK N 3 Yogyakarta [Skripsi]. Universitas Negeri Yogyakarta.

Uka, A. (2014). Student Satisfication As An Indicator of Quality in Higher Education. Journal of Educational and Instructional Studies, 4(3), 610.

Wahyuni, L., Andani, M., Afriyani, Y., \& Andini, C. (2017). Analisis Motivasi Belajar Pada Siswa Kelas XI MIA 4 SMA Negeri 3 Kota Jambi Pada Mata Pelajaran Fisika. Gravity: Jurnal Ilmiah Penelitian dan Pembelajaran Fisika, 3(1), 90-99.

Winata, R., \& Friantini, R. (2019). Pengaruh Motivasi Belajar Terhadap Prestasi Belajar Matematika Siswa Kelas VIII SMPN 1 Kuala Behe. JIPM Jurnal Ilmiah Pendidikan Matematika, 7(2), 8592.

Yasir, M., Suarman, \& Gusnardi. (2017). Analisis Tingkat Kepuasan Siswa dan Motivasi Dalam Pembelajaran Kelompok (Cooperative Learning) dan Kaitannya Dengan Hasil Belajar Akuntansi di SMK Labor Binaan FKIP UNRI Pekanbaru. Pekbis Jurnal, 9(2), 77-90.

Zulfa, M. (2019). Hubungan Antara School Well-Being Dengan Motivasi Belajar pada Siswa SMA Negeri 6 Banda Aceh [Skripsi]. UIN Ar-Raniry 